ConNotas. Revista de crítica y teoría literarias / Vol. V, Núm. 9 / 2007

\title{
Hagiografía. Una mirada a la literatura didáctica del siglo XVII
}

\author{
Silvia Guadalupe Alarcón SÁnchez
}

\section{Resumen:}

Luego de la escisión cultural que supuso la etapa de la Conquista, el periodo virreinal de la América hispana tuvo como prioridad instaurar un paradigma no sólo epistemológico sino sobre todo moral que permitiera el control en virtud de la homogeneización del pensamiento. La hagiografía -ahora considerada un subgénero literario-, como relato de una persona ejemplar, pronto se convirtió en una de las herramientas principales para llevar a cabo tal ejercicio didáctico. Debido a que en estos textos se conjugan la verdad histórica y la leyenda, además de que en ellos se subordina la objetividad a la retórica persuasiva, resulta inevitable que haya hibridez discursiva. En este trabajo se analizan las similitudes y diferencias que la hagiografía guarda con otros géneros narrativos como la autobiografía, la biografía, la crónica y la novela.

\section{Palabras clave:}

Hagiografía, autobiografía, Colonia, escritos monacales, hibridez.

Las hagiografías son relatos de vida que tienen como característica contar hechos singulares con un fin moralizante. En este trabajo se realiza un estudio descriptivo a partir de la lectura directa de un conjunto de hagiografías, la mayoría hispanoamericanas pertene- 
cientes al siglo XVII. ${ }^{1}$ La intención es caracterizar el corpus revisado y analizar la relación de la hagiografía con otros géneros narrativos como la biografía, la crónica y la novela.

Nombres insignes como el de Sor Juana Inés de la Cruz, Carlos de Sigüenza y Góngora y Juan Ruiz de Alarcón han traspasado las fronteras de nuestro país; sin embargo, existieron otras voces que no han sido escuchadas y que fueron representativas en la época virreinal. Esas voces pertenecen a religiosas que vivieron enclaustradas y, en algunos casos, fueron sentenciadas por la Inquisición. Las autobiografías y biografías constituyeron un género popularizado en el siglo XVII, y su escritura estuvo a cargo de religiosos. En esa época la noción que se tenía de literatura era ambigua. La cercanía entre historia e literatura se mantuvo estrecha, por lo que varios estudios sobre esos textos se han inclinado a anjudicarles un carácter histórico. Uno de los primeros aspectos que salta a la vista en la lectura de las hagiografías es su carácter indefinido: en sus páginas existe hibridez. Dice Munguía Zataráin que el relato tiene su origen en ciertas tradiciones:

1. Una fuente oral que provenía de leyendas, relatos, anécdotas y de un singular modo de narrar.

2. Trabajos históricos que se valían de casos, anécdotas, válidos como material literario. (35)

Debido a que la historia estuvo considerada como un género literario, no es difícil comprender por qué las hagiografías tenían esa hibridez entre lo literario y lo histórico; tal hibridez responde también a su doble propósito: además de mostrar lo ejemplar, "debía deleitar con una narración amena y propiciar la emotividad para producir la acción” (Rubial, “Ángeles” 20). Para ello los autores recurrían al uso de figuras retóricas como la repetición, el hipérbaton, la falsa modestia, la humildad, la alabanza, la desaprobación de acciones, la descripción de imágenes, el señalar a Dios como el guía en sus escritos, entre otras estrategias.

\footnotetext{
${ }^{1}$ Véase el corpus al final del ensayo.
} 
Existe actualmente una tendencia a revisar los estudios virreinales ya no como mera copia de prácticas escriturales españolas, por el hecho de que la literatura hagiográfica acompañó a la evangelización, sino como un conjunto de discursos de diferentes tipos: religiosos, históricos, literarios. La causa de que los textos monacales no se hayan considerado como parte de la historia literaria se debe a que abordan temas místico-religiosos que cumplían una función doctrinal y didáctica y parecían apartarse de lo estrictamente literario. Entre estos textos figuran las hagiografías, en las que se conjugaban - sin que fuera fácil diferenciarlas- la verdad histórica y la leyenda y en las que se subordinaba la objetividad a la retórica de persuasión dominante, propiciando que el público acogiera bien estas obras con todo y el elemento sobrenatural que portaban.

\section{Lo hagiográfico, lo biográfico, lo novelesco}

La biografía hagiográfica, como la llama Kathleen Myers (371), junto con otros relatos como la novela picaresca, perteneció a la narrativa barroca popular; de ahí que este tipo de historias fuera muy solicitado en la época; esto pudo haber sido un antecedente de lo que actualmente se conoce como novela, según lo sugiere la misma autora.

Algunos estudiosos dicen que los cronistas son considerados antecesores de los actuales novelistas, aunque con mayor certeza se les puede aplicar ese término a los hagiógrafos. Autores como Antonio Rubial indican que por la manera de presentar a los personajes, como arquetipos, el género está más cercano a la novela que a la historia, aunque existe la pretensión de que esos textos expresan hechos reales. La hagiografía tomó de la novela los

[...] cambios marcados por los tonos de fortuna y las vicisitudes, lo que le da a la narración suspenso y un tono de aventura [...] en el caso de la novela de caballería [...] la exageración y licencia para romper los planos entre la realidad y la ficción 
con la narración de hechos prodigiosos. [...]. También la retórica contribuyó normando la manera de escribir y el Barroco agregó el rebuscamiento del idioma, las digresiones. El sermón y el teatro, otros géneros que tuvieron gran difusión proporcionaron "su forma grandilocuente y rebuscada". (Santidad 31-41)

La mezcla de historia y literatura tuvo influencias de la novela de caballería en el sentido de que se suscitaban luchas entre el bien y el mal, resultando siempre vencedor el primero, esto último con el fin de ejemplificar. Su estructura contaba con los siguientes componentes:

[...] división de la obra en libros; protagonismo del biografiado; progresión en el tiempo y el espacio; cambios marcados por los tonos de fortuna y las vicisitudes lo que le da a la narración suspenso y un tono de aventura; convenciones físicas (belleza igual a bondad) y familiares (linaje ilustre, familia cristianísima, niñez ejemplar); sentido de la fama y la trascendencia entre los hombres. (Rubial, "Espejo" 90)

En el siglo XVI los cronistas de Indias produjeron textos con algunas características similares a las de las novelas, y en el siglo XVII lo hicieron las monjas con sus escritos de Vidas: "Los textos hagiográficos novohispanos, llenos de narraciones y anécdotas, no únicamente suplieron la casi total ausencia de literatura novelada, sino que fueron el antecedente de lo que en nuestros días se ha dado en llamar realismo mágico..." (Rubial, "Santos" 87). Por su parte, Teodosio Fernández afirma que existe una relación entre lo 'maravilloso cristiano' y lo sobrenatural, pues

un creyente puede estar seguro de la posibilidad de los milagros o de la existencia de los demonios, pero no dejará de relacionar eso con lo sobrenatural, con una dimensión que no es la suya, con un universo misterioso en el que se puede creer pero que no se puede razonar. (294) 
Justamente una de las particularidades de estos textos radica en la constante presencia de lo sobrenatural, o, como dijo Jacque Le Goff, 'lo maravilloso cristiano' (14). Un ejemplo que muestra hechos extraordinarios se localiza en el siguiente pasaje, obtenido de la autobiografía de Úrsula Suárez, monja chilena:

[...] y vi dentro del espejo un negro... Yo espantada de no haber visto venir de la chacra, ni un columpio que estaba en la sala donde este negro se columpiaba; apesarada de no haberlo visto venir...volví la cara...y ni había columpio ni negro, ni otra persona en toda la sala...y hallé al negro ya descubierto y tan sumamente feo que causaba horror verlo. (109)

Este fragmento se repite con algunas modificaciones en las historias de vida que cuentan las religiosas, en las cuales ocurren hechos sobrenaturales que giran alrededor de las biografiadas y que parecieran haber sido sacados de la mente de un novelista, como ocurre en la Vida ejemplar y muerte preciosa de la Madre Barbara Josepha de San Francisco, escrita por Fr. Miguel de Torres, o como en las tres parte[s] de los prodigios de la omnipotencia y milagros de la gracia en la vida de la venerable sierva de Dios Catharina de San Joan natural del gran Mogor, difunta en esta imperial ciudad de la Puebla de los Ángeles, elaborada por el P. Alonso Ramos, cuyo personaje, sin haber sido monja, vivió entregada a las normas que dictaban las órdenes religiosas y cuya vida estuvo llena de peripecias.

Si el siglo XVI se había caracterizado por discursos llenos de aventura, de acción, en los que los hechos de la conquista y la evangelización habían sido los principales temas; ahora la escritura se ocupaba de la contemplación, de la descripción, de la sensibilidad íntima, elementos que acogió la hagiografía. Se trata de textos que provenían de autobiografías escritas por religiosas en 'cuadernos de manos' y biografías cuyos autores eran sus confesores.

Una de las razones de la buena acogida del público era que no sólo moralizaron sino que también entretuvieron contando hechos sorprendentes, y es probable que estos acontecimientos hayan inte- 
resado más por sí mismos que por lo ejemplar. Entre los personajes que aparecen en las hagiografías se encuentran Cristo, la Virgen, ángeles y demonios, almas en pena y santos.

En algunos textos se notan divergencias, como el no estructurar el contenido en capítulos, en libros, y en otros casos los manuscritos no tuvieron signos de puntuación. También existía el uso del diálogo directo o indirecto, que proporcionaba el efecto de veracidad mediante un acercamiento al lenguaje oral, producto del recuerdo.

Las características que poseían las hagiografías en cuanto a su composición eran fundamentalmente dos: "una de orden literario, relacionada con lo narrativo, el discurso y el entretenimiento; la otra, asociada con lo moralizante, lo didáctico, lo ejemplar, lo edificante" (Rubial, "Espejo" 89). Las hagiografías, al igual que la predicación, ${ }^{2}$ reflejaban las costumbres y modos de ser del auditorio, por lo que es consecuente pensar que estaban hechas a la medida de lo que se quisiera inculcar. Los escritos estuvieron dirigidos a un público que gozaba leyendo exageraciones e imaginaciones propias de personajes arquetípicos, aceptando lo sobrenatural proveniente de la fe religiosa.

Uno de los rasgos esenciales de la hagiografía fue el absoluto protagonismo de la heroína; sobre ella sabemos más detalles que de cualquier otro personaje: su nombre y apellidos, los nombres de sus padres y el dato de su lugar de origen; al morir, su cuerpo emanaba un aroma suave y dulce; poseían el don de profecía, de ubicuidad, de penetración en las mentes; realizaban milagros y prodigios; eran visionarias y ayudaban a las almas del purgatorio.

La mayoría de las obras tenían tres componentes: el biográfico, el histórico y el literario. El biográfico dio cuenta de la vida de la religiosa; el histórico tocó aspectos propios de su condición de santidad: su vida en el convento, la convivencia de varias clases sociales, las instituciones, los poderes que se entrecruzaron; dentro de lo literario convergieron lo biográfico, lo histórico, la retórica religiosa

${ }^{2}$ Esta actividad fue sumamente valorada en esa época. 
y el acervo popular. En algunos casos se percibía entre líneas la historia propia de las autoras, aunque su presencia fue escasa, ya que se debe tener en cuenta que las monjas no hablaban por sí solas, sino que era Dios quien se expresaba tomándolas como intermediarias. Esta situación se presenta como una doble negación de la voz de las monjas: por parte de Dios y por parte del confesor.

Existían varios motivos para la escritura de una crónica o de una hagiografía; entre ellos pueden mencionarse el de dar a conocer un lugar, sus habitantes, formas de comportamiento, vestir, pensar, comer, en fin, todos esos aspectos que pudieron haber causado curiosidad a los lectores de tierras lejanas; otro, el de dar testimonio de la grandeza obtenida por la hazaña de la conquista; uno más es la intención de querer emular a la madre patria con narraciones similares a las que se producían en ella. Una forma de hacer llegar a los ojos europeos la bondad de la tierra a la que se había llegado era a través de la descripción del lugar; para ello se presentó una naturaleza pródiga y a sus habitantes maquillados con virtudes, teniendo en cuenta que aquellos que definían esas cualidades eran los criollo; ellos estaban forjando la historia que harían suya tomando en cuenta su carácter letrado.

En algunos textos es posible advertir una forma impersonal de dirigirse al receptor, lo cual sugiere que no era el confesor a quien la religiosa tenía en mente, sino a otros posibles lectores. Es probable que la autora pensara que su escrito pudiera tener utilidad práctica; para ello escribía de acuerdo con las normas de la escritura hagiográfica de la época, que tomaba en cuenta condiciones culturales e históricas como la escritura por mandato, propia de la época virreinal, y la necesidad de reforzar la fe cristiana, lo cual le proporcionó una perspectiva de publicación que perfiló su voluntad de ser leída. Es posible que algunas religiosas pensaran en lectores que pertenecieran no sólo a su época sino también a los de años futuros; esta suposición se relaciona con lo que indica Manuel Ramos Medina, aludiendo a la crónica escrita por fray Alonso Franco: “QQué razón hay para que se prive al siglo presente y a los que vienen de ejemplares tan grandes y que por cercanos y próximos no 
tengamos noticia los que hoy somos y que se reserve su noticia para los venideros y que han de ser aquí a cien años?...” (418).

El escribir fue una actividad no permitida al común de las monjas, por lo que fue llevada a cabo sólo por unas cuantas. Fue una práctica vigilada, controlada y verificada; sirvió para sostener la santidad monacal y, en ocasiones, para acusarlas de herejes. La escritura de la monja se convertía en un diálogo en el que ella era la locutora y el interlocutor era el confesor, quien oía, descifraba y ordenaba: "Las apropiaciones discursivas tuvieron una función social y política muy importante para la iglesia católica" (Lavrin y Loreto 8). Mediante ellas se describió historias de personas ubicadas en un tiempo y en un lugar que sirvieron para consolidar la religión en la América virreinal y para que perviviera la cultura europea.

Las religiosas escribían sus autobiografías por mandato de sus confesores; sus escrituras muestran importantes similitudes, como, por ejemplo, la expresión de las dificultades para llegar a Dios, con los consecuentes auto-tormentos, ayunos, oración continua; se hacía hincapié en las lecturas espirituales; los escritos se inclinaban hacia lo irracional; la muerte como fin de las penas; milagros post mortem; "el desprecio del mundo, de sus riquezas y placeres, sobre todo los sexuales, por lo que el celibato era imprescindible" (Rubial, "Santos" 53). Existieron elementos recurrentes y comunes entre escritos europeos y americanos, tales como imágenes, metáforas, sangre, agua, visiones, entre otras; el uso de estas figuras facilitó la comprensión o bien contribuyó a la descripción concreta de situaciones o sentimientos. También existía la presencia de personajes humanos y sobrenaturales: "El héroe hagiográfico es un personaje que se debe plegar a las acciones que lo significan” (Bravo 116). Entre sus atributos estaban: virtudes tales como humildad, pobreza, castidad, pureza; ejemplaridad, pruebas y tentaciones de Dios y el demonio; debían magnificarse las virtudes más que los individuos. La vida del héroe se exponía en forma cronológica, y la vida en el convento transcurría fuera del tiempo mundano.

El estilo de la obra contenía formas de narración oral, descripción de penitencias y éxtasis con un ritmo lento; las mortificaciones 
eran narradas con lujo de detalles: señalaban modestia de recursos, alejamiento del mundo, asunción de una función religiosa, cumplimiento de milagros pre y postmortem, muerte en santidad. Otras constantes eran: un lenguaje característico del barroco de Indias, referencias a la Biblia, invención de estratagemas cuyo objetivo era salvaguardar una expresión propia; uso de figuras que movieron al auditorio como hipérboles, apóstrofes, interrogaciones, exclamaciones; recursos como los tropos, mediante los cuales una palabra recibía un significado que no era precisamente el correspondiente; utilización de un lenguaje asequible para el vulgo sin ocupar palabras rebuscadas.

Como parte de la retórica de la época está la utilización de un lenguaje con carácter repetitivo, una doble discursivización: el de la autora y el del confesor (véase Quispe Agnnoli); se trataba de un discurso alterado y manipulado por los varones, pues debía seguir las consignas oficiales: oralidad en el modelo comunicativo; en algunos casos, la revelación de una conciencia de poder en el uso del lenguaje; la concesión de autoridad, que en varios ocasiones recayó en Dios, tratando de evitar algún castigo inquisitorial. En algunos casos aparece la inserción de relatos distintos de la biografiada, contados por otras monjas, lo cual da idea de una autoría colectiva.

Las autobiografías monacales fueron consideradas formas de confesión, aunque en algunos casos las escritoras podían intercalar en sus autobiografías algunos pensamientos aparte de lo propiamente confesional: "Sólo aquello que yo mismo puedo decir de mi persona forma parte de la confesión [...] la confesión es inmanente a la conciencia que avanza moralmente" (Bajtín 126). La confesión fue vista como un acto virtuoso en el que las confesantes tenían que decir absolutamente todo aquello que fuera pecaminoso y eso estuvo implícito en la hagiografía. En la autobiografía se da una transmutación de la personalidad, por eso el que escribe hace un análisis desde el Otro; es como mirarse ante un espejo, aunque la vista no alcance a definir todos los rasgos, y además cuenta la subjetividad del autor. Se narra la historia de una primera persona que sólo existe en el presente de su enunciación, y en donde la escritura del 'yo' es legitimada por la Iglesia, institución para la que se escribía; el 
énfasis no está puesto en presentar rasgos psicológicos, pues todo lo expuesto se relaciona con Dios y su religión, aunque sí acusa la individualidad.

La obra de Philippe Lejeune, Le pacte autobiographique (1975), es reveladora en varios aspectos y nos guía en el análisis: dota a la autobiografía y a la biografía del carácter de género; la describe como ente literario y no histórico o psicológico, como antes se consideraba; introduce el término autor como parte importante en los estudios autobiográficos, aunque las marcas de éste quedan al margen del texto y lo considera como una persona que escribe y publica. Lejeune propone un pacto ficcional o novelesco donde se manifiestan dos aspectos: identidad entre autor y personaje o entre autor y narrador.

En las hagiografías puede ocurrir que el nombre propio del autor coincida con el del personaje lo cual remite al pacto autobiográfico, o bien tal coincidencia no se dé, lo cual hace pensar en la biografía. Cuando leemos una novela sabemos que es ficticia; cuando leemos una autobiografía pensamos que es verídica; el grado de verosimilitud diferencia estos dos géneros y tiene que ver con lo que Philippe Lejeune llamó pacto autobiográfico. En la lectura de las autobiografías religiosas nosotros creemos en la existencia histórica del autor, aunque algunos de los acontecimientos nos hagan dudar.

La cita que ofrece Albert Camus en "L'énigme", texto publicado en L'Eté, es sugerente para nuestro estudio: "Las obras de un hombre retratan con frecuencia la historia de sus nostalgias o de sus tentaciones y casi nunca su propia historia, sobre todo aquellas que se pretenden autobiográficas. Ningún hombre osó jamás pintarse tal como es" (citado en Prado Biezma 218). En este sentido, las autobiografías de las religiosas no cuentan totalmente la verdad; se trata de historias fabricadas con hechos reales pero también con la imaginación que les proporcionaba la fe; de ahí que las vidas de las mujeres autobiografiadas fueron inasequibles para la mayoría de los fieles; había una enorme dificultad de parecerse a ellas, lo cual era el objetivo del texto.

A partir de la escritura todo lo recordado es provocado por la memoria: 
La autobiografía es siempre una re-presentación, esto es un volver a contar... La vida es siempre, necesariamente, relato: relato que nos contamos a nosotros mismos, como sujetos, a través de la rememoración... No depende de los sucesos sino de la articulación de esos sucesos, almacenados en la memoria y reproducidos mediante el recuerdo y su verbalización [...] El lenguaje es la única forma de que dispongo para 'ver' mi existencia. (Molloy 16)

La temporalidad adoptada por las hagiografías era de tipo cronológico, con la peculiaridad de referirse primero a los antepasados, luego a los padres y después al nacimiento del personaje. Se usó la primera persona en singular, la selección de anécdotas representativas y significativas. Las causas por las que una persona se extendía o hablaba acerca de su nacimiento se debían al orgullo de haber sido descendiente de nobles, de padres ricos o muy religiosos; es así que las religiosas tomaban en cuenta el relato de su niñez aun cuando la mayoría de los autobiógrafos lo omitían. En las autobiografías se hacían exclusiones de hermanos y padres, dando así la impresión de que el único mundo que importaba, las únicas acciones, eran las del mundo conventual. Intentaron recuperar diacrónicamente la existencia pasada; fueron monofónicas, lineales, y tuvieron un ritmo continuo y progresivo; existió un narrador omnisciente que penetró en los hechos, en las intimidades.

Algunas obras no sólo estuvieron dirigidas a la comunidad de religiosas sino que también pretendieron modificar conductas; tuvieron un público más amplio y una función didáctica que variaba según se dirigiera a hombres o a mujeres. En las monjas existió una posición ambivalente, pues por un lado tuvieron que aceptar las condiciones que la sociedad les exigía en cuanto a escritura y que no podían rechazar debido a su condición de mujer, como el dictaminarles el cómo y el qué debían escribir; y por otro lado se valieron de estrategias discursivas y retóricas para hacerse oír. La escritura monacal puede verse como una palabra marginada en varios sentidos: es desposeída de autoría y esto fue parte de las características escriturales de la época; sin embargo, escribiendo buscaban el 
poder, aun cuando estuviera disfrazado por la palabra masculina. Los textos no competían con los de los varones pues estaban en desigualdad cultural; sus receptores se reducían a un público femenino cautivo. Como parte de su retórica hicieron alusión a su ignorancia como estrategias para protegerse de la censura. Asimismo el cuerpo se convirtió en un aliado contra la presión masculina y fue usado como medio de expresión de la santidad. Otra maniobra narrativa era mostrada cuando las monjas mismas escribían acerca de lo que se les prohibía, argumentando que su escritura servía para gloria de Dios; esto se oponía con la interdicción impuesta por los religiosos que les ordenaron callar. Las monjas se valieron de recursos para manipular los textos con el fin de lograr la autorrepresentación deseada; la realidad fue metamorfoseada, como, por ejemplo, cuando hablaban de sexo: lo encubrían a través de metáforas. Asimismo, lo desagradable fue deformado, tratando de evitar aquello que no era recomendable dar a conocer.

Entre las monjas existieron diferencias con respecto a su estilo de escritura, que tuvieron que ver con su nivel de educación, con las estrategias utilizadas para legitimar su vOz, con la expresión de sus experiencias místicas, con su origen social. El quehacer de la escritura implicaba algunos peligros considerando que existía un férreo control por parte de la Inquisición. De hecho, algunos escritos se consideraron transgresores, ya que sus palabras atentaban contra el bienestar moral de la sociedad. En ese sentido el fin moralizante que se buscaba se perdía, pues el texto se consideraba producto de la herejía. Como el discurso monacal estaba impregnado de pasajes sobrenaturales -que en ocasiones funcionan como historias independientes y a los que se les puede llamar relatos intercalados-, resultaba inquietante para sus censores y para su público. Una manera en que las autoras les daban coherencia era articulándolos con su vida personal, con sus experiencias, con su historias de vida. Los recuerdos de las experiencias debían ser contados con toda veracidad, pues conllevaban el peligro de caer en visiones demoníacas. Por otra parte, si las fuerzas del mal eran vencidas, la gloria, el reconocimiento y la posible santidad eran baluartes que convertían a sus autoras en heroínas. Sus obras no estuvieron pen- 
sadas para la publicación ni para que otros las leyeran. Posiblemente hubo excepciones, pues aunque algunas se quejaron del trabajo escritural, otras lo aceptaron y escribieron gran cantidad de páginas dedicadas a la comunidad a la que pertenecían.

Se tiene conocimiento de que las biografías convertidas posteriormente en hagiografías tuvieron buena acogida, y no solamente en el siglo XVII, que es el que nos ocupa, sino también posteriormente. Un ejemplo lo constituye la vida de Mariana de Jesús, titulada Santa Mariana de Jesús. Vida y novena indulgenciada, originaria de Ecuador. El autor de esta hagiografía, Aurelio Espinosa Pólit, tiró 5,800 ejemplares en la primera edición de 1950; en una segunda edición, ese mismo año, 20,000, y en 1951, 40000 ejemplares (Espinosa 1). Esto nos da una idea de la importancia de esta literatura llamada didáctica.

\section{Conclusiones}

La autobiografía y la biografía que se desarrollaron en el siglo XVII se enfocaron más en el mensaje que a en la vida de la mujer que contaban. Los biógrafos-confesores se convirtieron en críticos de las palabras de las religiosas; introdujeron opiniones digresivas a manera de moralejas, insistiendo en el aspecto moralizante, y se constituyeron en guías de los lectores.

Las hagiografías sirvieron para dar fe, para reforzar un imaginario colectivo religioso, para ganar una identidad en la que confesores o directores espirituales fueron colaboradores y guías; propiciaron la propagación de las ideas de las religiosas y el conocimiento actual de esas obras en nuestros días. La conjunción de Dios-confesor-escritora dio cauce a un río de letras, de voces, que ahora forman parte de nuestra cultura literaria hispanoamericana. 


\section{Corpus analizado}

\begin{tabular}{|c|c|c|c|c|c|c|c|}
\hline Autor(A) & TÍtulo & IMPRESIÓN & $\begin{array}{l}\text { LUGAR } \\
\text { DE } \\
\text { IMPRESIÓN }\end{array}$ & AÑo & $\begin{array}{l}\text { FECHA } \\
\text { DE } \\
\text { NAC. }\end{array}$ & $\begin{array}{l}\text { ORdEN } \\
\text { ReLigiosa }\end{array}$ & \begin{tabular}{|l} 
ORIGEN \\
GEOGRÁFICO
\end{tabular} \\
\hline $\begin{array}{l}\text { Madre Josefa } \\
\text { de la } \\
\text { Providencia }\end{array}$ & $\begin{array}{l}\text { Relación del origen y } \\
\text { fundación del monasterio } \\
\text { del Señor San Joaquín } \\
\text { de las religiosas nazarenas } \\
\text { carmelitas Descalzas de } \\
\text { esta ciudad de Lima, } \\
\text { contenida en algunos } \\
\text { apuntes de la viday } \\
\text { virtudes de la venerable } \\
\text { madre Antonia Lucía del } \\
\text { Espiritu Santo, fundadora } \\
\text { del instituto nazareno, } \\
\text { escrita por su hija, la } \\
\text { madre Josefa de la } \\
\text { Providencia subpriora de } \\
\text { dicho monasterio con las } \\
\text { licencias necesarias. }\end{array}$ & $\begin{array}{l}\text { Impresa en } \\
\text { la Imprenta } \\
\text { Real de los } \\
\text { Niños } \\
\text { Expósitos } \\
\\
\\
\end{array}$ & Lima & 1793 & 1646 & Nazarena & Lima, Perú \\
\hline $\begin{array}{l}\text { Gómez Haro, } \\
\text { Enrique }\end{array}$ & $\begin{array}{l}\text { Sor María de Jesús. } \\
\text { El lirio de Puebla }\end{array}$ & $\begin{array}{l}\text { Impresa por } \\
\text { el Monasterio } \\
\text { de la Purísima } \\
\text { Concepción. }\end{array}$ & & 1946 & 1579 & $\begin{array}{l}\text { Inmaculada } \\
\text { Concepción } \\
\text { de María }\end{array}$ & $\begin{array}{l}\text { Puebla, } \\
\text { México }\end{array}$ \\
\hline
\end{tabular}




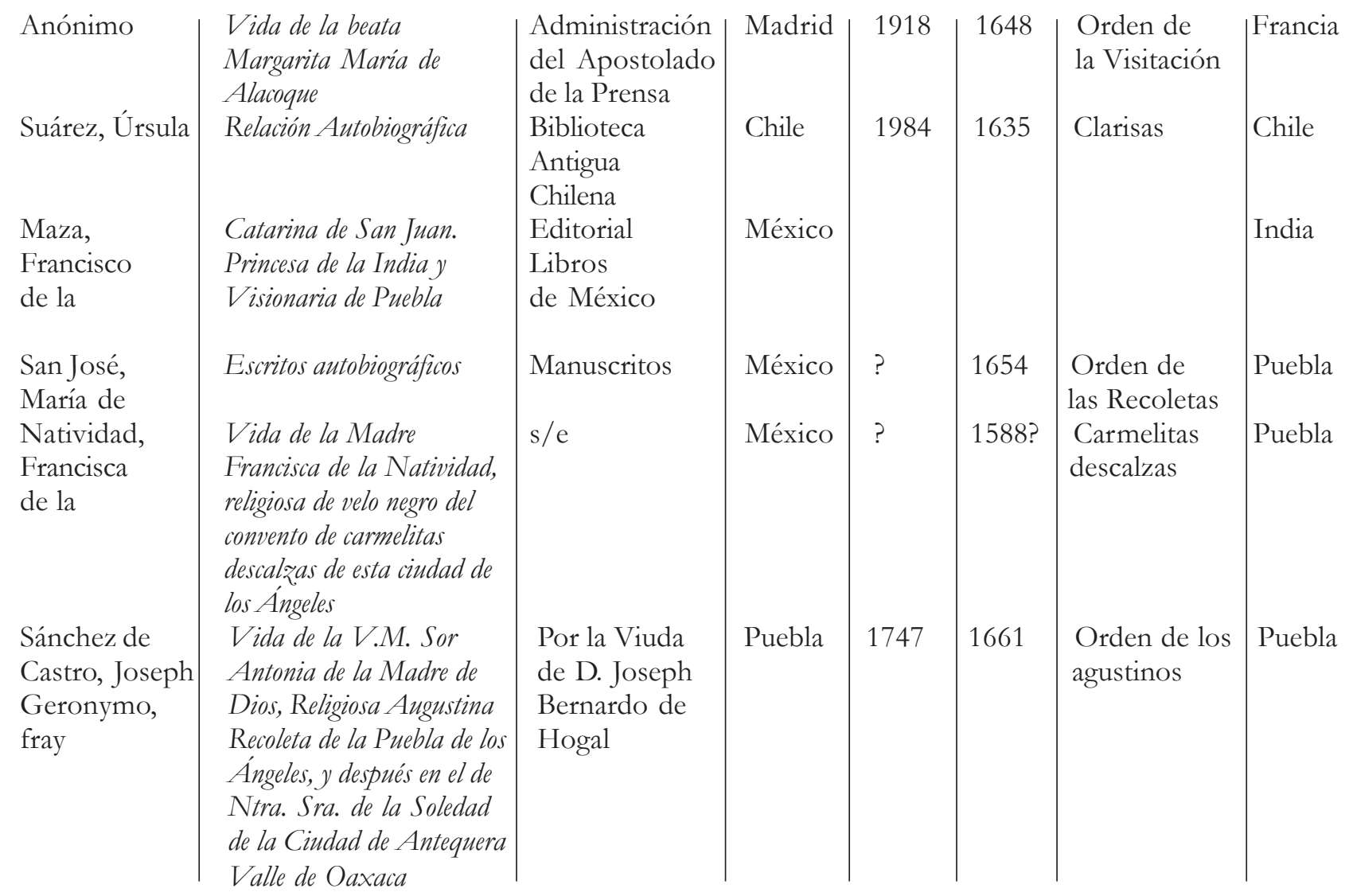




\begin{tabular}{|c|c|c|c|c|c|c|c|}
\hline $\operatorname{Autor(A)}$ & Título & IMPRESIÓN & $\begin{array}{l}\text { LUGAR } \\
\text { DE } \\
\text { IMPRESIÓN } \\
\end{array}$ & $\begin{array}{l}\text { AÑo } \\
\text { DE } \\
\text { NAC. }\end{array}$ & FECHA & $\begin{array}{l}\text { ORDEN } \\
\text { RELIGIOSA }\end{array}$ & $\begin{array}{l}\text { ORIGEN } \\
\text { GEOGRÁFICO }\end{array}$ \\
\hline $\begin{array}{l}\text { Gómez, } \\
\text { Joseph, fray }\end{array}$ & $\begin{array}{l}\text { Vida de la venerable madre } \\
\text { Antonia de San Jacinto } \\
\text { Monja profeffa de velo negro, } \\
\text { e hija de el Real, y } \\
\text { Religiofiffimo Convento de } \\
\text { Santa Clara de Jesús de la } \\
\text { Ciudad de Santiago de } \\
\text { Queretaro }\end{array}$ & $\begin{array}{l}\text { Imprenta de } \\
\text { Antuerpia de } \\
\text { los Herederos } \\
\text { de la Viuda } \\
\text { de Bernardo } \\
\text { Calderón }\end{array}$ & México & 1689 & & clarisas & $?$ \\
\hline $\begin{array}{l}\text { Félix de Jesús } \\
\text { María }\end{array}$ & $\begin{array}{l}\text { Vida, virtudes y dones } \\
\text { sobrenaturales de la Ven. } \\
\text { Sierva de Dios Sor Maria } \\
\text { de Jesús, religiosa professa } \\
\text { en el V. Monasterio de la } \\
\text { Inmaculada Concepción de } \\
\text { la Puebla de los Ángeles en } \\
\text { las Indias Occidentales }\end{array}$ & $\begin{array}{l}\text { Imprenta de } \\
\text { Joseph y } \\
\text { Phelipe de } \\
\text { Rossi }\end{array}$ & Puebla & 1756 & 1579 & $\begin{array}{l}\text { Concepcio- } \\
\text { nista }\end{array}$ & Puebla \\
\hline $\begin{array}{l}\text { Lemus, Diego } \\
\text { de }\end{array}$ & $\begin{array}{l}\text { Vida, virtudes, trabajos, } \\
\text { favores y milagros de la } \\
\text { venerable Madre Sor } \\
\text { María de Jesús, } \\
\text { angelopolitana religiosa, }\end{array}$ & $\begin{array}{l}\text { A costa de } \\
\text { Anisson y } \\
\text { Pascual }\end{array}$ & León & 1653 & 1579 & $\begin{array}{l}\text { concepcio- } \\
\text { nista }\end{array}$ & Puebla \\
\hline
\end{tabular}




\begin{tabular}{|c|c|c|c|c|c|c|c|}
\hline Francisco & $\begin{array}{l}\text { natural de ella... } \\
\text { Vida de la Ven. Madre }\end{array}$ & Gabriel de & Madrid & 1670 & $?$ & Recoleta & ? \\
\hline Ignacio & $\begin{array}{l}\text { Isabel de Jesús recoleta } \\
\text { Agustina en el convento de } \\
\text { San Ivan Baptista dictada } \\
\text { por ella misma y añadido } \\
\text { lo que faltó de su dichosa } \\
\text { muerte }\end{array}$ & $\begin{array}{l}\text { León, } \\
\text { mercader } \\
\text { de libros }\end{array}$ & & & & Agustina & \\
\hline $\begin{array}{l}\text { Siria, Antonio } \\
\text { de }\end{array}$ & $\begin{array}{l}\text { Vida admirable y } \\
\text { prodigiosas virtudes de la } \\
V . \text { Sierva de Dios D. } \\
\text { Anna Guerra de Jesús } \\
\text { sacada de lo que ella misma } \\
\text { dejó escrito por orden de sus } \\
\text { confesores }\end{array}$ & $\begin{array}{l}\text { Br. Antonio } \\
\text { de Velasco }\end{array}$ & Guatemala & 1716 & 1639 & $?$ & $\begin{array}{l}\text { San } \\
\text { Salvador }\end{array}$ \\
\hline
\end{tabular}




\begin{tabular}{|c|c|c|c|c|c|c|c|}
\hline AUTOR(A) & TÍTUlO & IMPRESIÓN & $\begin{array}{l}\text { LUGAR } \\
\text { DE } \\
\text { IMPRESIÓN }\end{array}$ & $\begin{array}{l}\text { AÑO } \\
\text { DE } \\
\text { NAC. }\end{array}$ & FECHA & $\begin{array}{l}\text { ORDEN } \\
\text { RELIGIOSA }\end{array}$ & $\begin{array}{l}\text { ORIGEN } \\
\text { GEOGRÁFICO }\end{array}$ \\
\hline $\begin{array}{l}\text { Torres, Miguel } \\
\text { de }\end{array}$ & $\begin{array}{l}\text { Vida ejemplar y muerte } \\
\text { preciosa de la Madre } \\
\text { Barbara Josepha de San } \\
\text { Francisco religiosa de velo } \\
\text { y choro del convento de la } \\
\text { Santíssima Trinidad de } \\
\text { la Puebla de los Ángeles }\end{array}$ & $\begin{array}{l}\text { Por los } \\
\text { Herederos de } \\
\text { la Viuda de } \\
\text { Francisco } \\
\text { Rodríguez } \\
\text { Lupercio }\end{array}$ & Puebla & 1725 & 1622 & Franciscana & Caracas \\
\hline $\begin{array}{l}\text { Sigüenza y } \\
\text { Góngora, } \\
\text { Carlos }\end{array}$ & $\begin{array}{l}\text { "Vida de la V. Madre } \\
\text { Marina de la Cruz" en } \\
\text { Paraíso occidental }\end{array}$ & $\begin{array}{l}\text { Consejo } \\
\text { Nacional para } \\
\text { la Cultura y } \\
\text { las Artes }\end{array}$ & México & 1995 & 1536 & $\begin{array}{l}\text { Carmelitas } \\
\text { descalzas }\end{array}$ & Alcalá la Real \\
\hline $\begin{array}{l}\text { Sigüenza y } \\
\text { Góngora, } \\
\text { Carlos }\end{array}$ & $\begin{array}{l}\text { "Introdúcese la vida } \\
\text { de la V.M. Inés de la } \\
\text { Cruz refiriendo con } \\
\text { sus propias palabras su } \\
\text { prodigiosa niñez, lo que } \\
\text { ocasionó su venida a la } \\
\text { Nueva España y lo que } \\
\text { en México le sucede", } \\
\text { en Paraíso occidental }\end{array}$ & $\begin{array}{l}\text { Consejo } \\
\text { Nacional para } \\
\text { la Cultura y } \\
\text { las Artes }\end{array}$ & México & 1995 & 1570 & $\begin{array}{l}\text { Carmelitas } \\
\text { descalzas }\end{array}$ & Toledo \\
\hline
\end{tabular}




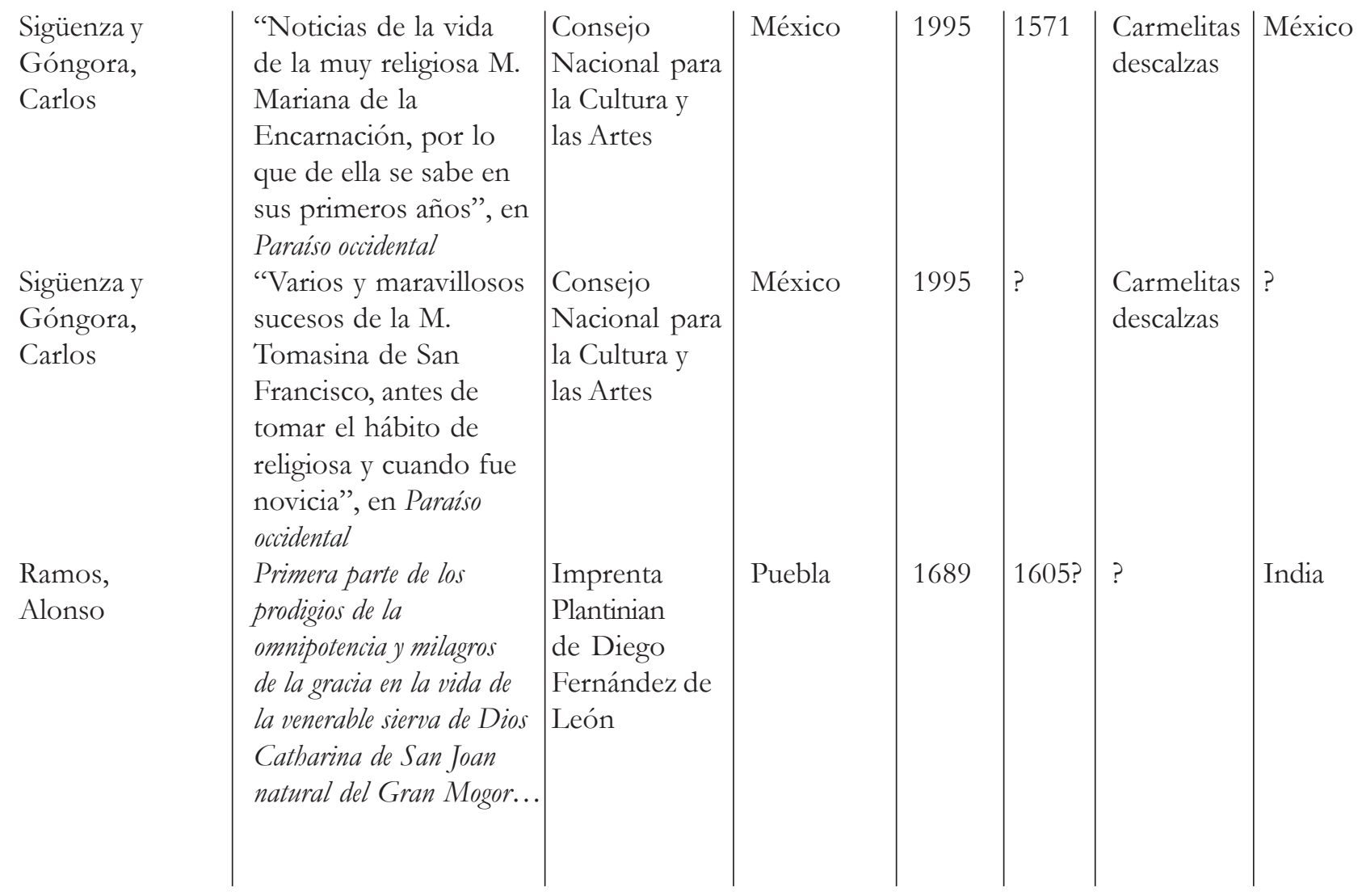




\section{Bibliografía}

Bajtín, M. M. Estética de la creación verbal. Tr. Tatiana Bubnova. México: Siglo XXI editores, 1982.

Bravo Arriaga, María Dolores. La excepción y la regla. México: UNAM, 1997.

Certeau, Michel de. La Fábula Mística. Siglos XVI-XVII. Tr. Jorge López Moctezuma. México: Universidad Iberoamericana, 1993.

Espinosa Pólit, Aurelio. Santa Mariana de Jesús. Vida y novena indulgenciada. Ecuador: Artes Graficas, 1951.

Fernández, Teodosio. "Lo real, maravilloso de América y la literatura fantástica." Teorías de lo fantástico. Comp. David Roas. Madrid: Arco/Libros, 2001.

Lavrin Asunción y Loreto Rosalva L., eds. La escritura femenina en la espiritualidad barroca novohispana siglos XVII y XVIII. México: Universidad de las Américas/Archivo General de la Nación, 2002.

Lejeune, Philippe. Le pacte autobiographique. Paris: Seuil, 1975.

Le Goff, Jacques. Lo maravilloso y lo cotidiano en el Occidente medieval. Barcelona: Gedisa, 1986.

Molloy, Sylvia. Acto de presencia. La escritura autobiográfica en Hispanoamérica. México: El Colegio de México, FCE, 1996.

Munguía Zatarain, Martha Elena. Elementos de poética histórica. El cuento hispanoamericano. México: El Colegio de México, 2002.

Myers, Kathleen. "¿'Testimonio para la canonización o prueba de blasfemia? La nueva Inquisición española y la biografía hagiográfica de Catarina de San Juan." De palabras, imágenes y símbolos. Homenaje a José Pascual Buxó. Coords. y eds. Enrique Ballón Aguirre y Óscar Rivera Rodas. México: UNAM, 2002.

Quispe Agnnoli, Rocío. "Escritura femenina en los conventos coloniales. Control y subversión.” Mujeres latinoamericanas: Historia y cultura. Siglos XVI al XIX. Coord. Luisa Campuzano. Ed. Clara Hernández. Serie Coloquios, 35. La Habana: Casa de las Américas/UAM, 1997.

Prado Biezma, Javier del, Juan Bravo Castillo, María Dolores Picazo. Autobiografía y modernidad literaria. España: Ediciones de la Universidad de Castilla-La Mancha, 1994. 
Ramos, Alonso. Primera parte de los prodigios de la omnipotencia y milagros de la gracia en la vida de la venerable sierva de Dios Catharina de San Joan natural del gran Mogor, difunta en esta imperial ciudad de la Puebla de los Ángeles. Puebla: Imprenta de Diego Fernández de León, 1689.

Ramos Medina, Manuel. "Los cronistas de monjas: la traducción masculina de una experiencia ajena." Historia de la literatura mexicana 2. La cultura letrada en la Nueva España del siglo XVII. México: Siglo XXI, 2002.

Rosa Nicolás. El arte del olvido (Sobre la autobiografía). Buenos Aires: Puntosur editores, 1990.

Rubial García, Antonio. "Espejo de virtudes sabrosa narración, emulación patriótica. La literatura hagiográfica sobre los venerables no canonizados de la Nueva España." La Literatura Novohispana. Revisión crítica y propuestas metodológicas. Eds. José Pascual Buxó y Arnulfo Herrera. México: UNAM, 1994.

"Los santos milagreros y malogrados de la Nueva España." Manifestaciones religiosas en el mundo colonial americano. Coords. Clara García Ayluardo y Manuel Ramos Medina. México: INAH /Condumex/UIA, 1997.

"Ángeles en carne mortal. Viejos y nuevos mitos sobre la evangelización de Mesoamérica." Signos históricos 7 (2002): 19-51. La santidad controvertida. Hagiografía y conciencia criolla alrededor de los no canonozados de la Nueva España. México: UNAM/FCE, 1999.

Suárez, Úrsula. Relación Autobiográfica. Chile: Biblioteca Antigua Chilena, Academia Chilena de la Historia, 1984. 